\title{
ArcheoSciences
}

Revue d'archéométrie

31 | 2007

Varia

\section{Woodland in the middle Ebro valley (Spain). Dendrological analysis of archaeological timber from Bell Baker and Iron Age periods}

La forêt autour de la moyenne vallée de l'Ebre (Espagne). Résultats préliminaires de l'étude dendrologique des bois de construction archéologiques du Campaniforme et de l'Âge du Fer

\section{Yolanda Carrión Marco}

\section{(2) OpenEdition}

\section{Journals}

Electronic version

URL: https://journals.openedition.org/archeosciences/865

DOI: $10.4000 /$ archeosciences.865

ISBN: 978-2-7535-1596-3

ISSN: $2104-3728$

Publisher

Presses universitaires de Rennes

\section{Printed version}

Date of publication: 31 December 2007

Number of pages: 151-161

ISBN: 978-2-7535-0618-3

ISSN: $1960-1360$

\section{Electronic reference}

Yolanda Carrión Marco, "Woodland in the middle Ebro valley (Spain). Dendrological analysis of archaeological timber from Bell Baker and Iron Age periods", ArcheoSciences [Online], 31 | 2007, Online since 31 December 2009, connection on 01 February 2022. URL: http://journals.openedition.org/ archeosciences/865; DOI: https://doi.org/10.4000/archeosciences.865 


\title{
Woodland in the middle Ebro valley (Spain). Dendrological analysis of archaeological timber from Bell Baker and Iron Age periods
}

\author{
La forêt autour de la moyenne vallée de l'Ebre (Espagne). \\ Résultats préliminaires de l'étude dendrologique des bois de construction \\ archéologiques du Campaniforme et de l'Âge du Fer
}

\author{
Yolanda CARrión Marco*
}

\begin{abstract}
In this paper, the results of the dendrological analysis of timber from three archaeological sites are presented. This material comes from the wooden structures of different kinds of buildings (houses, walls and a funerary dolmen). For this task, a small number of vegetal species were used. Dendrological analyses are perfectly adapted to this research, since ecological, climatic and human events can be inferred from the observation and measurement of tree growth-rings. To implement the method in this region is particularly interesting because of the lack of palaeoenvironmental studies. Micro- and macroscopic observation of wood charcoal enables wood identification: mainly pine and juniper were selected for timber from among all the species identified from charcoal analyses in other archeological contexts (fireplaces, occupation levels, etc.). The samples with a longer radius were measured on a dendrological bench. Generally, the growth rate was very low in most of the specimens.

Résumé : Les résultats de l'étude dendrologique réalisée sur les bois de construction de trois sites archéologiques seront présentés. Il sagit de bois de construction carbonisés sur place. Le principal intérêt de cette étude est la reconstitution des paléo-paysages, mais aussi des systèmes humains d'approvisionnement du bois et de gestion de la forêt, dans une région où l'information paléoenvironnemental en général est encore faible. L'examen microscopique et macroscopique du charbon de bois a permis de déterminer les essences végétales choisies pour la construction, essentiellement pin et genévrier, parmi un grand nombre d'essences utilisées que l'on connaît d'après l'analyse anthracologique en autres contextes (foyers, fours, sols d'occupation). La largeur des cernes de croissance radiale du bois, qui enregistrent les principaux événements climatiques et anthropiques, a été systématiquement mesurée. Ces données ont livré des informations intéressantes sur la densité des forêts, l'impact des conditions climatiques sur la croissance des plantes et l'évolution des formations végétales sur une longue séquence. La plupart des individus des trois sites présentent une taxe de croissance très basse.
\end{abstract}

Key words: Timber, Dendrology, Palaeoenvironment, Woodland management, Bell Baker, Iron Age.

Mots clés : Bois de construction, Dendrologie, Paléoenvironnement, Exploitation forestière, Campaniforme, Âge du Fer.

* MEyC Post-doctorante, UMR CNRS 6566 - Université de Rennes 1, Laboratoire Archéosciences-Rennes, Beaulieu, 35042 Rennes cedex. (yolanda. carrion@univ-rennes1.fr) 


\section{Description of THE Sites AND CURRENT ENVIRONMENT}

The Ebro River has the highest rate of flow in the Iberian peninsula, and its river system gives rise to very varied ecosystems. The sites we are presenting in this study are located in the middle valley, but had very different climatic and ecological conditions (Fig. 1), and cover a time-span from the Bell Baker period to the Iron Age.

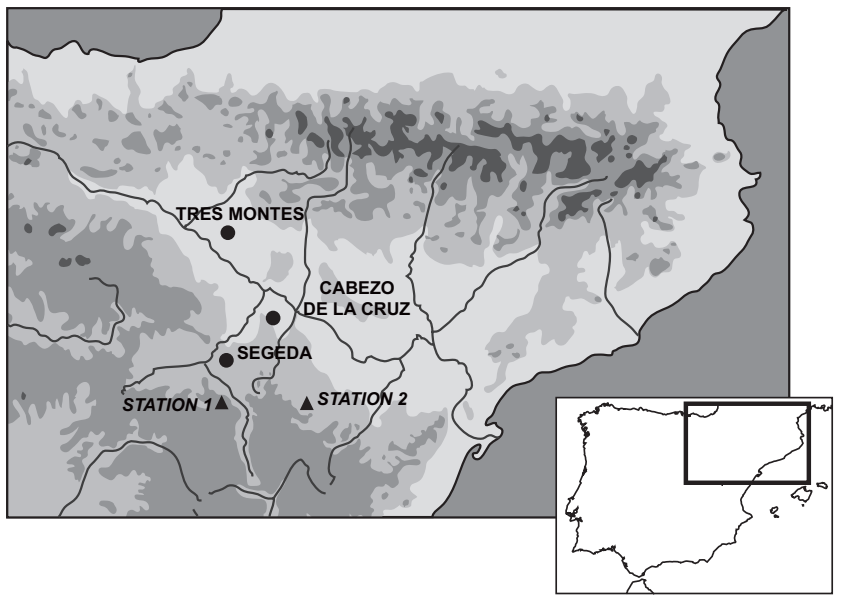

Figure 1: Location map of the sites and sampling stations. Figure 1: Carte de localisation des sites et des stations de prélèvements.

The Bell-Baker dolmen of Tres Montes is located in a natural region called Bardenas Reales, 370 m.o.s.l. Because of the continental influence, the annual rains hardly reach $400 \mathrm{~mm}$, with torrential rainfalls, long summer droughts and cold winters. Erosive processes are very intense and there is a characteristic relief with high plains and deep gorges, and vegetation is sub-desertic and steppelike (Elósegui Aldasoro \& Ursúa Sesma, 1994; Elósegui Aldasoro et al., 1990). There are some plant populations perfectly adapted to these biogeographical conditions, such as shrubs of rosemary (Rosmarinus officinalis), several species of thyme (Thymus), Cistaceae (Helianthemum cinereum subsp. rubellum, Helianthemum pillosum, Fumana ericoides, Fumana thymiflora) and legumes. On northern slopes, flax (Linum suffruticosum) and common box (Buxus sempervirens) develop (Elósegui Aldasoro \& Ursúa Sesma, 1994). Along the streams, some tamarisks (Tamarix canariensis), Chenopodiaceae and "esparto" grass (Stipa tenacissima) are adapted to the salty soils and sandy sediments carried by the torrential waters. Only on northern slopes can some arborean vegetation develop, mainly Aleppo pine (Pinus halepensis) and a dense bushy layer of Kermes oak (Quercus coccifera), buckthorn (Rhamnus lycioides, Rhamnus alaternus), narrow-leaved vetch (Phillyrea angustifolia), prickly juniper (Juniperus oxycedrus), Phoenician juniper (Juniperus phoenicea), Spanish juniper (Juniperus thurifera) and mastic (Pistacia lentiscus).

The charcoal of this study comes from the main wooden frame structure of the megalithic monument, destroyed by a big fire. The preservation of carbonised wood offers very valuable information about its construction, use and abandonment. The monument was composed of a room (of $4.20 \times 3.40 \mathrm{~m}$, and $2 \mathrm{~m}$ below ground level) and a corridor. There was evidence of a woody supporting structure along the walls, with 65 posts in a perimetral ditch, and other ones in the middle of the room, possibly supporting the covering structure (Andrés Rupérez et al., 2001). Radiocarbon dates were obtained directly from the timber: $4330 \pm 110 \mathrm{BP}$ and $4080 \pm 100$ BP (Sesma Sesma, 1993).

Cabezo de la Cruz is located on a smooth hill over the left lowland of the river Ebro. Nowadays, landscape surrounding the site is very altered by human farming, and natural vegetation has almost completely disappeared. The village was occupied during the Epipalaeolithic, the Bronze Age and the Iron Age (Rodanés \& Picazo, 2006). The latter period provided all the carbonised material for this study, since a fire destroyed the houses but preserved all the wooden supporting elements.

The Iron Age village of Segeda is located on the edge of the Ebro basin and the Iberian mountain range. This is an area of bioclimatic transition, between meso- and supramediterranean conditions, with an annual average temperature of $13.7^{\circ} \mathrm{C}$ and $434 \mathrm{~mm}$ of precipitation (Rivas-Martínez, 1987: 117). Wild vegetation is rare around the site, because of the intensive cereal farming, but some woodlands of Pinus pinaster grow in nearby mountains.

The principal aim of this study is to reconstruct the growth patterns of vegetation and the climate conditions of the past from dendrological analyses, since other palaeobotanical studies are rare in the region. The use of vegetal resources for fuel or timber is related to the environmental availability, so reconstructing vegetation also facilitates archaeological discussion about human technology and forest management.

\section{Material AND MEthodS}

Our analysis encompasses the general aims of dendrology: to approach ecological, climatic and historical questions from the study of tree growth-rings. Dendrological studies from prehistoric sites have recently multiplied, both on wood and charcoal, and the results are often successful 
in spite of the frequent difficulties of studying these kinds of materials (Pétrequin, 1989, 1997; Pétrequin \& Pétrequin, 1989; Bernard, 1998; Marguerie, 1992a, 1995a \& b, 1998; Marguerie \& Marcoux, 2001; Marguerie \& Hunot, 2007; Bosch et al., 2000). Human and palaeoenvironemntal information inferred from archaeological charcoal is much appreciated because it allows identification of the wood species used for fuel or timber, the construction techniques and the fire conditions.

For charcoal identification and dendrological analysis, both micro- and macroscopical observation are required.

The botanical identification of wood species is possible using a metallurgical microscope that allows a magnification factor of 100 to 500 times (Vernet, 1973; Vernet et al., 1979). The anatomical patterns of each species are observed on the three sections of wood, and compared with a reference collection of current carbonised woods, anatomy atlases and a specialised bibliography (Metcalfe, 1960; Metcalfe \& Chalk, 1950; Greguss, 1955, 1959; Jacquiot, 1955; Jacquiot et al., 1973; Schweingruber, 1978, 1990, etc.). Thus, charcoal fragments can be identified to the species, genus or family level, depending on the similarities of their anatomy. When a higher magnification is required, charcoal can be observed through a Scanning Electron Microscope.

Moreover, some of the growth features of the samples can be observed under low magnification. One of the bases of dendrology is that the normal growing rhythm of a plant can be altered by both internal and external agents, such as climatic conditions, human exploitation, animal grazing, microorganism attack, and so on (Munaut, 1988; Marguerie, 1992a; Schweingruber, 1996). These are some of the dendrological analysis criteria we have examined:

- Tree-ring width, which is a direct reflection of the radial growth of the plant.

- Tree-ring bending, which can show the part of the tree where the sample comes from (Hunot, 2000: 12; Marguerie $\&$ Hunot, 2007).

- The presence of the pith and/or the bark: this way, we can measure the complete radius of the stem, and discover the felling season, depending on the bark position.

- The presence of tyloses in some deciduous species, which can mark the difference between the heartwood and the sapwood (Esau, 1985: 275).

- Compression wood, which is a reaction to non-vertical elements, such as branches, bent stems and changes in the stand of the tree (Kaennel \& Schweingruber, 1995).

- Radial cracks: these seem to be a result of green wood burning, because there is a rapid moisture loss, which makes the wood contract (Marguerie, 1992a \& b; Théry-Parisot, 2001).
- Vitrification of cellular tissues: causes are not clear, but it could be related to the use of green wood and to low-oxygen combustion (Théry-Parisot, 2001; Fabre, 1996; Tardy, 1998; Thinon, 1992; Scheel-Ybert, 1998; Carrión, 2005).

- The presence of fungi and xylophagous insects, which give rise to an interesting discussion about the state of the collected wood (dead, green, altered...) (Théry-Parisot, 2001; Carrión \& Badal, 2004; Badal, in press).

- The human work of wood can be documented from polished, shaped, squared... surfaces. Wood tools are preserved only in some special archaeological contexts (Petréquin, 1989, 1997; Petréquin \& Petréquin, 1989; Bosch et al., 2000; Lull et al., 1999).

The tree-ring measurement was carried out using a binocular lens, with low magnification (between 8 and 32) on a measuring bench which allows displacement of the sample with a precision of $0.01 \mathrm{~mm}$. We built the database using not only tree-ring widths but also all the previously mentioned parameters along with their graphical and statistical treatment.

We studied 11 carbonized posts from the megalithic monument of Tres Montes. There, a woody supporting structure was documented along the walls, with 65 posts in a perimetral ditch, and other ones in the middle of the room, possibly supporting the cover frame. From Cabezo de la Cruz, 113 pieces of timber and two collections of little branches (numbering 100) were analysed. Finally, we took 34 samples of wood from the wall system of the village of Segeda.

\section{RESUlts OF THE ANALYSES}

\section{Wood selection and properties}

The palaeoflora of a site is the list of all the taxa identified from charcoal fragments, that is to say, those selected by human groups from among all the available vegetable resources. Generally, a small number of species are collected for timber on the basis of the physical and technical features of the wood, so they are not suitable for palaeovegetation reconstruction (Chabal, 1997), but these can be a good indicator of human management of woodland, and also technological-economical patterns can be inferred.

For palaeovegetation reconstruction, a sufficient number of charcoal fragments coming from several domestic fires are required. In Cabezo de la Cruz and Segeda, charcoal analyses from fires, domestic wastes and occupation soils have been carried out as well, so we can approach the wood selection 
for timber in relation to all the available species (Badal, in press; Pérez et al., in press) (Table 1).

\begin{tabular}{|l|c|c|c|c|c|}
\hline Site & Tres M. & \multicolumn{2}{|c|}{ Cabezo C. } & \multicolumn{2}{|c|}{ Segeda } \\
\hline Taxa presence & T & D.F & T & D.F. & T \\
\hline Arbutus unedo & & $*$ & & & \\
\hline Buxus sempervirens & & $*$ & & & \\
\hline Cistus sp. & & $*$ & & & \\
\hline Ephedra sp. & & $*$ & & & \\
\hline Fabaceae & & $*$ & & $*$ & \\
\hline Fraxinus sp. & $*$ & $*$ & & $*$ & $*$ \\
\hline Juniperus sp. & & $*$ & & & \\
\hline Labiatae & & $*$ & $*$ & $*$ & \\
\hline Pinus halepensis & & & & $*$ & $*$ \\
\hline Pinus nigra-sylvestris & & $*$ & & $*$ & \\
\hline Pinus pinea -pinaster & & $*$ & & & \\
\hline Pistacia lentiscus & & $*$ & & $*$ & \\
\hline Pistacia terebinthus & & $*$ & & $*$ & \\
\hline Prunus sp. & & $*$ & $*$ & $*$ & \\
\hline Evergreen Quercus & & $*$ & $*$ & $*$ & \\
\hline Deciduous Quercus & & $*$ & & & \\
\hline Rhamnus-Phillyrea & & $*$ & & $*$ & \\
\hline Rosacea-Maloidae & & $*$ & $*$ & & \\
\hline Rosmarinus officinalis & & $*$ & $*$ & $*$ & \\
\hline Salix-Populus & & $*$ & $*$ & & \\
\hline Tamarix sp. & & $*$ & & \\
\hline Vitis sp. & & $*$ & & & \\
\hline
\end{tabular}

Table 1: Presence of the taxa identified in the sites, from timber (T) and domestic fires (D.F)

Tableau 1 : Liste des taxons identifiés sur les sites en provenance de bois d'ouvre (T) ou de feux domestiques (D.F.).

In Tres Montes, a single genus has been identified, Juniperus sp. (Pl. I, ph. 1, $2 \& 3$ ), but not the species, because of their enormous similarity. Nevertheless, according to the rays height (Greguss, 1955) and to the current ecology in the region, the collected species might be Spanish juniper. The presence of this species points to an open vegetal landscape of supramediterranean type, although the selection of a single taxon does not allow further reconstruction of the plant populations.

In Cabezo de la Cruz, Aleppo pine has supplied most of the timber (91.6\%) (Pl. I, ph. $6 \& 7$ ), but Deciduous Quercus (1.68\%), Evergreen Quercus (2.5\%), Salix-Populus $(2.5 \%)$ and tamarisk (1.68\%) are also present. Trunks of these species have been used for the supporting structure of the houses, mainly posts inlaid into the mud walls. Some of them appear to have been worked, with one of the ends sharpened to a point, and secondary branches have been removed. In addition to the posts, several batches of small branches and stems of about 4-6 (up to 8) $\mathrm{mm}$ in diameter were sampled from the fire level on this site. These were probably part of the cover frames of the houses. For this task, the following taxa were used: Fabacea, Aleppo pine, rosemary, Salix-Populus and tamarisk. Some of these species (mainly willow and tamarisk) produce very flexible branches, suitable for plaiting the cover structure. The bark was preserved in most of the branches. From the observation of the bark position, in contact with latewood or earlywood, we can surmise the collection season. We noticed a predominance of bark in the latewood (Fig. 2), which means that the collection of wood was mainly carried out during the season unfavourable for growing; nevertheless, the presence of bark in both, latewood and earlywood, might be due to the repairing of the cover in several seasons.

In Segeda, only two species, black/Scots pine (Pinus nigra-sylvestris) (87.5\%) (Pl. I, ph. 4 \& 5) and Juniperus sp. $(12.5 \%)$ had been collected for timber while others, such as ash (Fraxinus), Prunus, Quercus, Salix-Populus and other species of pine, were identified in charcoal from metallurgical kilns and domestic contexts (Pérez et al., in press).

Why were pines mainly preferred for timber from among the available tree species? From their presence in charcoal from domestic wastes, there is no doubt about the availability of pines in the surrounding environment of the sites,

N.

Latewood $\square$ Earlywood

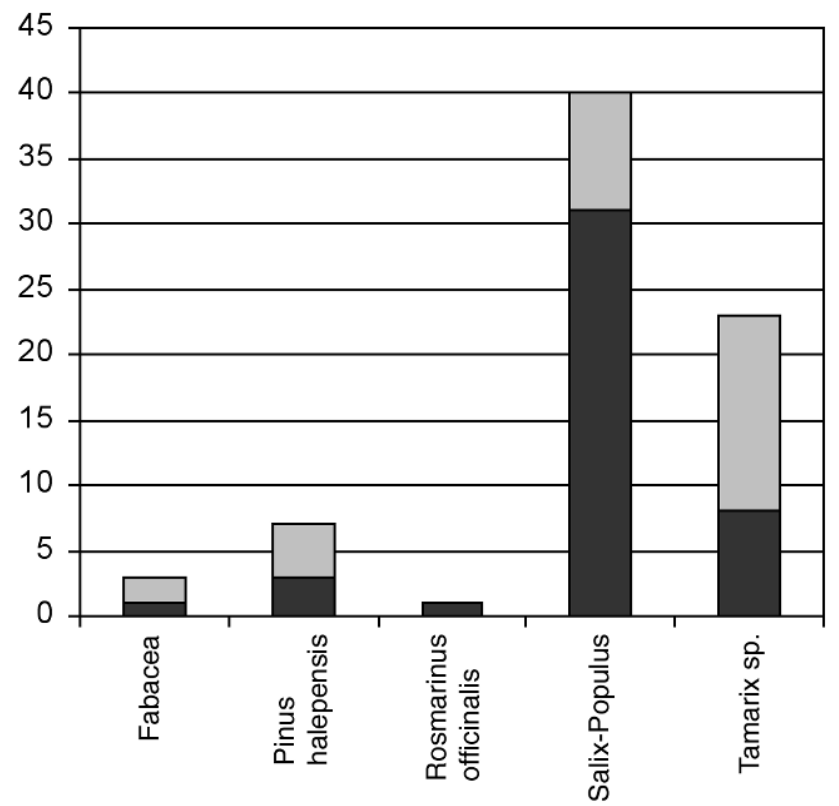

Figure 2: Season of wood collection from the presence of bark in wood from Cabezo de la Cruz.

Figure 2 : Saison de collecte du bois à partir de la position de l'écorce conservée sur les échantillons de Cabezo de la Cruz. 

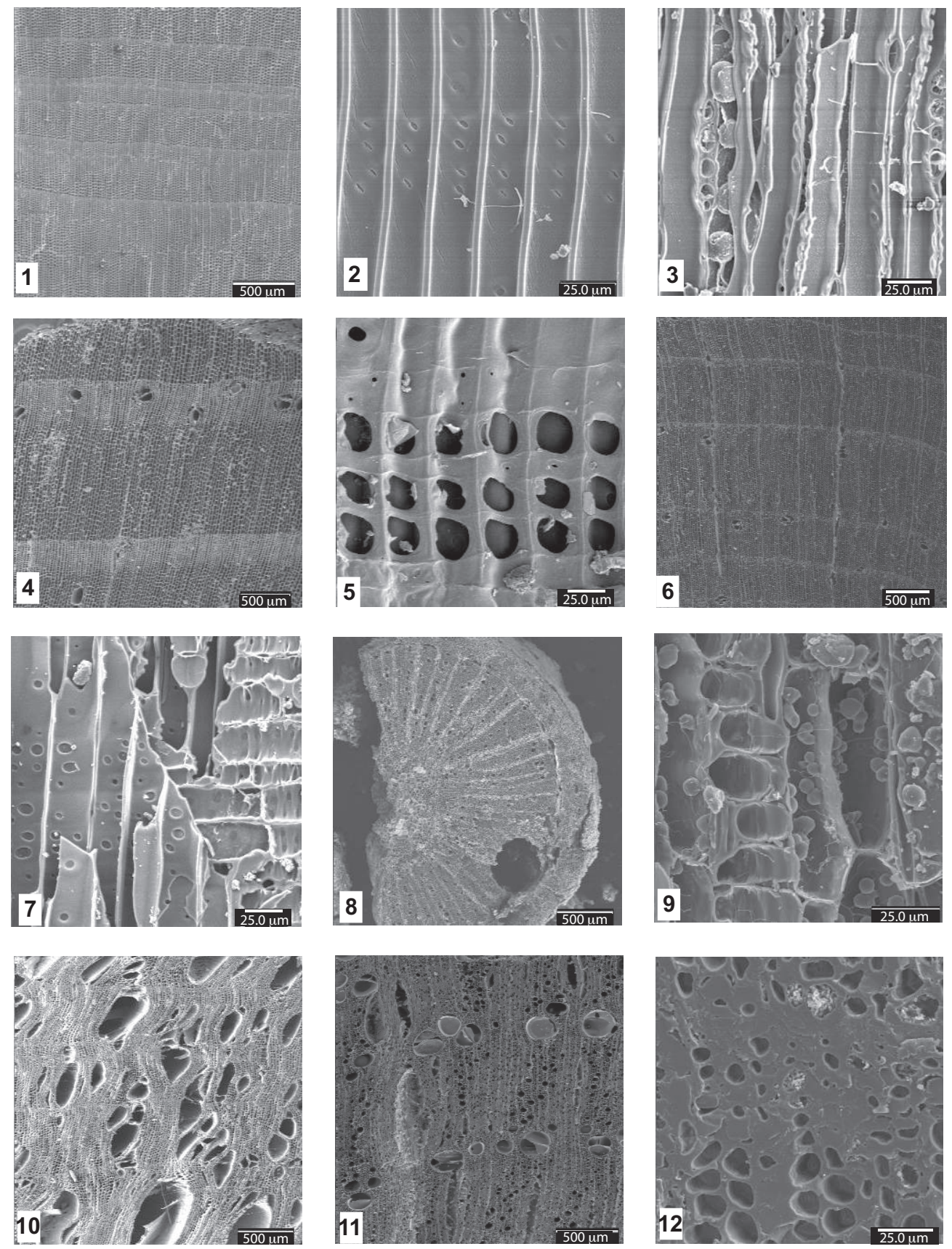

Plate I: Anatomy of some identified taxa: 1. Juniperus sp., Tres Montes, cross section; 2. Juniperus sp., Tres Montes, tangential section; 3. Juniperus sp., Tres Montes, radial section. 4. Pinus nigra-sylvestris, Segeda, cross section; 5. Pinus nigra-sylvestris, Segeda, radial section; 6. Pinus halepensis, Cabezo de la Cruz, cross section; 7. Pinus halepensis, Cabezo de la Cruz, radial section; 8. Tamarix sp., Cabezo de la Cruz, cross section with xylophagous gallery; 9. Pinus halepensis, Cabezo de la Cruz, tangential section, detail of fungal attack; 10. Pinus halepensis, Cabezo de la Cruz, cross section with radial cracks; 11. Deciduous Quercus, Cabezo de la Cruz, cross section with radial cracks; 12. Pinus halepensis, Cabezo de la Cruz, vitrified cross section.

Planche I: Anatomie de quelques taxons identifiés : 1. Juniperus sp., Tres Montes, coupe transversale; 2. Juniperus sp., Tres Montes, coupe tangentielle; 3. Juniperus sp., Tres Montes, coupe radiale. 4. Pinus nigra-sylvestris, Segeda, coupe transversale; 5. Pinus nigra-sylvestris, Segeda, coupe radiale; 6. Pinus halepensis, Cabezo de la Cruz, coupe radiale; 7. Pinus halepensis, Cabezo de la Cruz, coupe radiale; 8 . Tamarix sp., Cabezo de la Cruz, coupe transversale avec galeries de xylophages; 9. Pinus halepensis, Cabezo de la Cruz, coupe tangentielle, détail d'attaque fongique; 10. Pinus halepensis, Cabezo de la Cruz, coupe transversale avec fentes radiales; 11. Chêne à feuillage caduc, Cabezo de la Cruz, coupe transversale avec fentes radiales; 12. Pinus halepensis, Cabezo de la Cruz, vitrifié, coupe transversale. 
but other technical or mechanical criteria might have been implemented. Pines are technically softwood trees, although some species such as the Scotch pine have a hard, coarsegrained wood. All pines can produce thick, straight trunks, suitable for construction purposes.

\section{Wood alterations}

Microscopic analysis of charcoal has shown some frequent alteration of anatomical features, caused by fungal or insect attack, or during the combustion process (Table 2). The analysis of these alterations offers information about the state of collected wood and the fire conditions.

The presence of fungi hyphae is quite frequent in archaeological charcoal and wood (Théry-Parisot, 2001; Carrión \& Badal, 2004; Badal, in press). Wood decay occurs under environmental factors favorable for microbial development (such as high moisture and oxygen levels). Fungi grow in the wood and feed on it, developing through intervascular pits and along the vessels, until the whole structure is contaminated. The most interesting discussion about fungi presence in charcoal relates to the state of the collected wood (Théry-Parisot, 2001). Ethnographical studies have proved that dead wood was often collected for firewood (although contamination could also occasionally occur in living trees), but in archaeological contexts it is difficult to know if contamination took place before or after wood collection, or in archaeological diposits. Generally, wood collected for timber is preferred to be as healthy as possible, especially if it is going to be used as a supporting structure, because the fungal attack makes cell walls become brittle and distructured, and the wood loses hardness and resistance. Nevertheless, the presence of fungi is quite frequent in timber from the three sites (Pl. I, ph. $3 \&$ 9) so we think that contamination might have occurred after collection, during a stocking period or while timber was part of the wooden structures, exposed to air and moisture.

In Tres Montes timber, fungi were present in $100 \%$ of the charcoal samples, and the contamination degree was very similar in all of them: the hyphae development was still incipient (Pl. I, ph. 3). In Cabezo de la Cruz we have also very often identified the attack of microorganisms and insect channels (Pl. I, ph. 8). Most of the vegetal remains in Cabezo de la Cruz were preserved thanks to their complete carbonisation, but we have also documented the presence of fresh wood (4.2\% of the samples) and semi-carbonised wood $(10.92 \%)$. This wood is especially weak against xylophagous insects attack, which might have continued until the present day.

In charcoal from Cabezo de la Cruz, we have also noticed a high frequency of radial cracks (Pl. I, ph. $10 \& 11$ ) (Table 2). This alteration is presumed to take place during combustion of green wood or during its drying process when there is rapid moisture loss, which makes wood contract and break in a radial direction. $32.8 \%$ of timber from this site had radial cracks. As expected in accordance with the collection of green, flexible branches for the cover plaiting, this phenomenon is more frequent in this kind of wood.

We also observed the "vitrification" of vegetal tissues in a high percentage of charcoal from Cabezo de la Cruz (Table 2). This phenomenon consists of a gradual fusion of the whole cells, which gives the charcoal structure a glasslike surface, and often makes botanical identification difficult (Pl. I, ph. 12). Vitrification is currently being studied,

\begin{tabular}{|c|c|c|c|c|c|c|c|c|c|c|c|}
\hline \multirow[t]{2}{*}{ Site/Taxa } & \multicolumn{3}{|c|}{ Curvature } & \multirow{2}{*}{$\begin{array}{l}\text { Radial } \\
\text { cracks }\end{array}$} & \multirow{2}{*}{ Vitrified } & \multicolumn{2}{|c|}{ Xylophagous } & \multirow{2}{*}{$\begin{array}{c}\text { Reaction } \\
\text { wood }\end{array}$} & \multirow{2}{*}{$\begin{array}{l}\text { Fresh } \\
\text { wood }\end{array}$} & \multirow{2}{*}{ Pith } & \multirow{2}{*}{$\begin{array}{l}\text { Total } \\
\text { indiv. }\end{array}$} \\
\hline & Strong & Intermed & Low & & & Fungi & Insects & & & & \\
\hline \multicolumn{12}{|l|}{ Segeda } \\
\hline Juniperus sp. & 2 & 1 & & & & 1 & & & & & 4 \\
\hline Pinus nigra-sylvestris & 7 & 2 & 6 & 6 & & 4 & 2 & & & 2 & 28 \\
\hline \multicolumn{12}{|l|}{ Cabezo de la Cruz } \\
\hline Pinus halepensis & 86 & 16 & 7 & 34 & 65 & 65 & 31 & 23 & 17 & 36 & 109 \\
\hline Deiduous Quercus & 2 & & & 2 & 1 & 1 & & & & & 2 \\
\hline Evergreen Quercus & 3 & & & 1 & & 2 & & 2 & 1 & & 3 \\
\hline Salix-Populus & 2 & 1 & & 1 & & 2 & & & & & 3 \\
\hline Tamarix sp. & 1 & & 1 & 1 & 1 & 1 & 1 & & & & 2 \\
\hline \multicolumn{12}{|l|}{ Tres Montes } \\
\hline Juniperus sp. & 11 & & & 2 & & 11 & & 1 & & 1 & 11 \\
\hline
\end{tabular}

Table 2: Dendrological data of the timber samples.

Tableau 2 : Données dendrologiques des échantillons de bois d'euvre. 
but several hypotheses about its causes are being considered, such as high temperature combustion (Fabre, 1996; Tardy, 1998), the high moisture rate in wood (Thinon, 1992) or the use of green firewood (Scheel-Ybert, 1998). Experiments have not succeeded in reproducing vitrified charcoal in open fires (only a few fragments) but they did in low-oxygen fires (Théry-Parisot, 2001). In these cases, the interruption of the burning process made some substances - such as tar, resins, etc. - accumulate on the cell structure, producing this glazed aspect. The high percentages of vitrification identified in material from some archaeological features with the mentioned patterns (low oxygen input and/or closed structures) support this hypothesis (Carrión, 2005). In Cabezo de la Cruz, similar fire conditions have resulted from the accumulation of charred material during the fire.

\section{Results of tree-ring observation and measurement}

In spite of the high fragmentation of some charcoal samples, low-curvature growth-rings have been sysematically measured through a binocular lens with a caliper rule, in order to obtain the average radial growth. This was calculated for each fragment and for each species, so that the values from different sites containing the same species could be compared.

The diagrams of width-class distribution show the growing tendencies for the three sites (Marguerie \& Hunot, 2007) (Fig. 3). They are not very suitable for comparison with each other because they correspond to different species: juniper in Tres Montes, Aleppo pine in Cabezo de la Cruz and black/ Scots pine in Segeda. Nevertheless, an intra-site ecological approach can be inferred.

The graphic of Tres Montes shows a bimodal distribution of the values: most of them are between 0.25 and 0.625 , and a small group is between 0.75 and $1 \mathrm{~mm}$. The existence of very narrow rings often made measurement difficult; moreover, Juniperus species do not always have visible growth-ring boundaries when observed through the binocular lens and the presence of false rings also makes curve correlation difficult. This phenomenon is quite common in juniper and in other conifer species.

Several samples provided long series, exceeding 100 rings/ years. According to the similarities in the main events of the curves, two dendrological series were obtained, which points again to the sourcing of wood from two different forests, or at least, from two zones of the forest with different spatial arrangement of trees.

In Cabezo de la Cruz, the measurement of low-curvature growth-rings in Aleppo pines resulted in an average value
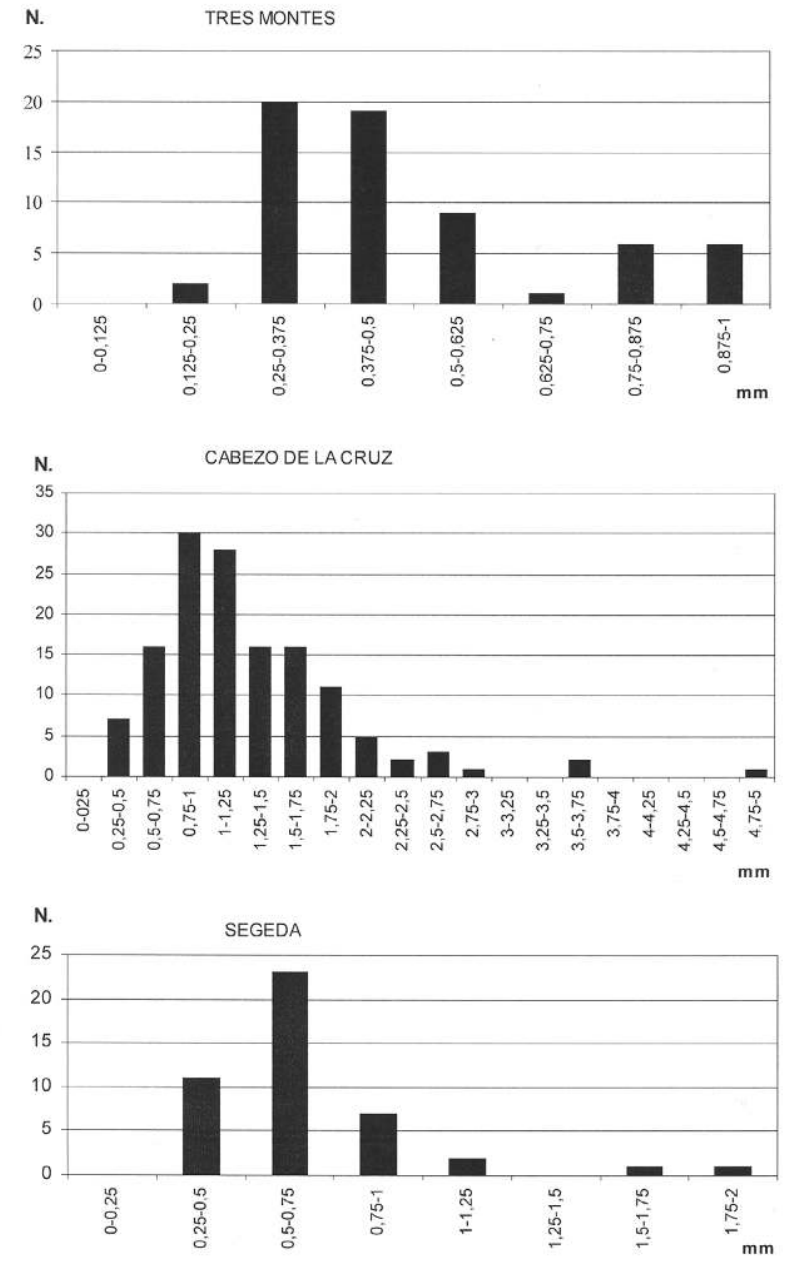

Figure 3: Histograms of width-class distribution of tree growthrings of junipers from Tres Montes, Aleppo pines from Cabezo de la Cruz and black/Scots pine from Segeda

Figure 3 : Histogrammes de classes de largeurs de cernes des genévriers de Tres Montes, des pins d'Alep de Cabezo de la Cruz et des pins noirs ou sylvestres de Segeda.

for ring width of $1.28 \mathrm{~mm}$. The annual growth rate is quite high, but unfortunately, the lack of references for this time period does not allow us to compare other data and to postulate the real density of vegetal populations.

The diagram of width-class distribution shows a unimodal pattern, although the values of average ring-width are arranged in an open interval between 0.5 and $2 \mathrm{~mm}$, and only a few individuals exceed these values. According to this, wood might have been collected in a single forest. The large interval of average growth values can also be seen from the curves of accrued growth values (Fig. 4), where we can surmise that wood might have been obtained from a high number of individuals, although most of them are distributed between 1 and $2 \mathrm{~mm}$. 

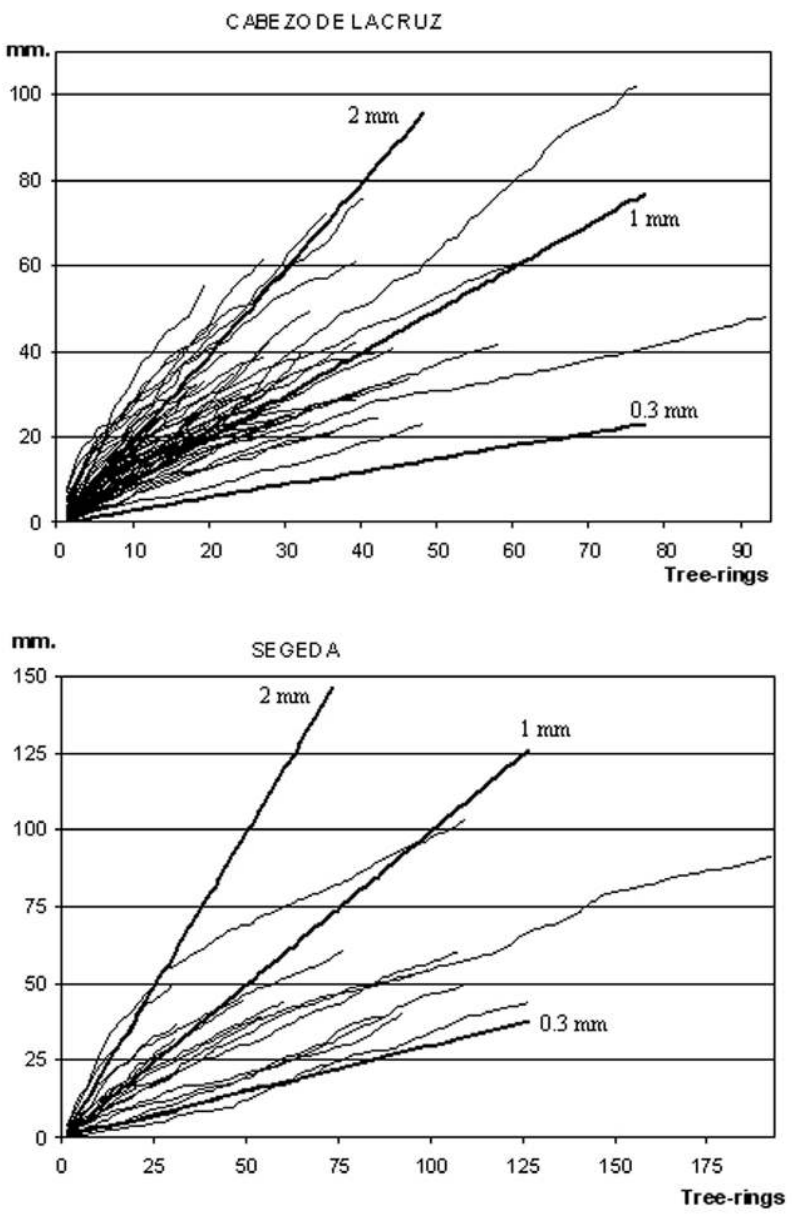

Figure 4: Graphics of accrued growing values of woods from Cabezo de la Cruz (Aleppo pine) and Segeda (black/Scotch pine), from Bernard, 1998: 96.

Figure 4 : Graphiques de valeurs cumulées de croissance des bois provenant de Cabezo de la Cruz (pin d'Alep) et Segeda (pin noir/sylvestre), d'après Bernard, 1998: 96.

In Segeda, tree-rings were measured in 18 samples of black/Scots pine, and an average growth rate of $0.68 \mathrm{~mm}$ was obtained. The graphic of width-class distribution (Fig. 3) shows a clear unimodal pattern, and therefore indicates wood collection from a single forest. Similarities in the curves resulting from the measurement series reveal that most of the wood samples came from a smaller number of trees, probably 3 or 4 individuals, which can also be noticed on the graphic of accrued growth values (Fig. 4), where three theoretical growing patterns of 2,1 and $0,3 \mathrm{~mm} /$ year are represented (corresponding to open, intermediate and dense forests, respectively).

The growth rates observed in pines from Cabezo de la Cruz and Segeda are quite different, having average values of 1.28 and $0.68 \mathrm{~mm}$ respectively. But, what are these differen- ces due to? Was there a real difference in the forests density, or is it due to the fact that we are comparing two different species of pine? We have sampled some living individuals from the surroundings of the sites with the purpose of finding the current differences in the growth rates of Aleppo pine and Scots pine developing in the same environment. There is a lack of unmanaged forests in the region, so we took the samples from two reforested areas with a minimum age of 40-50 years, to match wild forest growing patterns as closely as possible. Station 1 is located in the lower region of the Martín River, near the Epipalaeolithic rockshelter of Los Baños, at 506 m.o.s.l.; there, eight individuals from a population of Aleppo pine were sampled. Station 2 is located near the site of Segeda, at 925 m.o.s.l. We sampled eight individuals of each pine species present in the forest (Aleppo pine, cluster pine and Scots pine). Thus, differences between the growth rates of species living under the same climatic and human conditions can be compared. Cores were obtained with an auger, through the pith, in order to get the complete radius of the trunk. Growth-rings were measured using the same method as for the archaeological ones, and average growth values were obtained for each species.

Table 3 shows the results of the measurements. For current individuals, it is interesting to notice the differences in growth rates for each species from Station 2: $2.14 \mathrm{~mm}$ for Aleppo pine, 1.94 for Scots pine and 1.66 for cluster pine. On the other hand, Aleppo pine from Station 1 and Station 2 present similar growth rates, although they are located in the bottom and on the slope of the valley respectively. The annual growth rate is slightly higher in the bottom of the basin. According to these data, the growing rate in pines seems to be closely related to the species in our study area, where no obvious environmental differences have been noticed. Comparison with archaeological woods shows that there are very large differences in the growing rates in the same species (Aleppo pine for Cabezo de la Cruz, Scots pine for Segeda), so in both sites, the presence of a woodland denser than that of today can be inferred.

\begin{tabular}{|l|c|c|c|c|}
\hline Species/Site & C. Cruz & Segeda & Station 1 & Station 2 \\
\hline Pinus halepensis & 1.28 & - & 2,26 & 2.14 \\
\hline Pinus nigra-sylvestris & - & 0.68 & - & - \\
\hline Pinus sylvestris & - & - & - & 1.94 \\
\hline Pinus pinaster & - & - & - & 1.66 \\
\hline
\end{tabular}

Table 3. Comparison of growth average values $(\mathrm{mm})$ from archaeological and current woods.

Tableau 3: Comparaison des valeurs de croissance moyenne de bois archéologiques et actuels. 


\section{DisCussion}

The presence of carbonised or fresh wood in archaeological sites is a direct result of human management of vegetal resources, so they are suitable for providing interesting information about both ecological dynamics and human patterns in the exploitation of the environment. Generally, timber is selected according to the use it is destined for: sometimes, straight trunks are needed; at other times, flexible branches or stems are plaited for roofs and walls. Endurance and resistance to moisture, to the open air or to fungal attack are much appreciated qualities for timber. The fact that only a few species are usually selected for this task makes it difficult to postulate the real composition of vegetal populations.

In Tres Montes, a single taxon has been documented, Juniperus sp. There was also selection in the size of the trunks: those of the same diameter could have been obtained from trees of similar age or even from the same one, because juniper species are not always tree-like, and often have several branches from the base. In Segeda, black/Scots pine was mainly used as timber and, according to the growth patterns observed in the wood samples, it was taken from only a few trees ( 3 or 4$)$. At both sites the wood samples related to a short, sporadic activity (the construction of a burial monument and a defensive structure, respectively) so the wood collection might have been selective as well. On the other hand, Cabezo de la Cruz was a large village with many domestic features and a long-term occupation, so the collected wood was diversified, in species, in size, etc., although Aleppo pine was clearly preferred for timber.

From the species used for timber, we can infer their presence in the environment near the sites, but they have been selected from among other species developing there, so we can never know their real percentages or the woodland composition. Nevertheless, the larger presence of coniferous species such as junipers and pines, points to the existence of an open landscape of meso-supramediterranean type. It would be interesting to know the presence/absence of other arboreal species, because if shrub-like plants were in dominance, junipers and pines might have been collected just because of the lack of other trees for timber.

We can postulate regional vegetation from other palaeobotanical studies but, unfortunately, those are rare in this area. Pollen analysis carried out in the Bronze Age sites of Puy Aguila I and Monte Aguilar, near Tres Montes, indicates a landscape dominated by herbaceous and shrub species, characteristic of arid environments (Chenopodiaceae, Compositae, Poaceae, etc.) and very few trees (Iriarte, 1992, 2001). The layers prior to this habitation show more abundant tree vegetation, with Quercus t. ilex-coccifera and Pinus, and the highest percentage of Cupressaceae (which the genus Juniperus belongs to). Effects of tree felling become clearer in pollen sequences during Recent Prehistory, because pines and river species seemed to be more abundant before Bronze Age occupation (Iriarte, 1992). Reduction of arboreal vegetation occurs in parallel with the increase in pollen of Cerealia. This fact makes obvious the human causes of the disappearance of the forest. An interesting point in line with this idea is the gradual regeneration of pines where cereal crops are abandoned, so this genus must have a basic role in the potential regional vegetation, although it is not present in Tres Montes charcoal.

In Cabezo de la Cruz and Segeda, charcoal from other domestic features was also analysed (Badal, in press; Pérez et al., in press). In the first one, the content of domestic fires shows high percentages of pines, but also a large variety of bush species, such as Pistacia, Fabaceae, rosemary, evergreen Quercus, and so on. Other tree species were identified, such as strawberry tree (Arbutus unedo), ash, Pomoideae, SalixPopulus, tamarisk and yew (Taxus baccata) (Badal, in press), which indicates the presence of a well-developed riverside vegetation. Pine may be over-represented because of its use for timber, but it was already present in the Epipalaeolithic level of this site (Badal, oral com.), and in other nearby sequences (Valero-Garcés et al., 2000a \& b) before the emergence of farm technology able to intensely modify the landscape. For this reason, in contrast to the model that considers pines as secondary vegetation and a consequence of forest disturbances, these new data point to a natural status of this species, well adapted to the dry and warm conditions of the Ebro basin.

In Segeda, junipers are highly represented in occupation levels inside the village, and at least three pine species (black/ Scots pine, Aleppo pine and cluster pine) have been documented. These same species were identified in charcoal from Los Baños rockshelter, an Epipalaeolithic site located on the edge of the Ebro basin and the southern mountains (Badal, 2004). Apparently, the presence of several pine species with different needs in temperature and rainfall are a sign of ecological transition areas.

Dendrological analysis on conifers has made evident some methodological difficulties in growth-ring measurement of these species. The presence of false rings becomes clear in the curves displacement. This does not allow us to perfectly crossdate the series, even from the same individual. The existence of regional series or a high number of samples from the same site would help to correct the curves, but dendrological analyses in Spain are still incipient, so we have no reference for this region. In spite of these limitations, other ecological and climatic data have been obtained. 
In Tres Montes, a very low growth rate is distinctive in long curves. According to other authors, the precipitation levels are one of the main factors causing a very low rate of growth in conifers. A dendrological study carried out by Esper (2000) on a Juniperus population in Pakistan showed growth values between 0.24 and 0.42 for high mountain individuals, in contrast to those living at the bottom of the valley, with a higher rate of growth. Junipers are also very sensitive to extreme temperatures (Esper, 2000: 259). The Bardenas Reales are actually characterized by the heterogeneous precipitation (long drought periods and occasional, torrential rains) and great temperature contrasts (up to $45^{\circ} \mathrm{C}$ oscillations from day to night) (Elósegui \& Ursúa, 1994: 17-19), so these climatic patterns may have influenced plant growth.

As for woodland development and density, from comparison with current growth patterns in pines, we can infer that vegetal populations were denser during the Iron Age period, and a progressive expansion of open areas has occurred as a consequence of continuous human exploitation of woodland.

\section{Acknowledgements}

This work has been financed by the Spanish Ministry of Education and Science (Ministerio Español de Educación y Ciencia). We are also grateful to the staff of Proyecto Segeda for the logistical support in the study area and Dr. Ernestina Badal, from Valencia University, for her help with the fieldwork.

\section{References}

Andrés Rupérez, M.T., García García, M. L. and Sesma Sesma, J., 2001. El sepulcro campaniforme de Tres Montes (Las Bardenas Reales, Navarra). Intervención de urgencia de 1991 y campañas de 1996 y 1997. Trabajos de Arqueología de la Universidad de Navarra, 14. Pamplona.

BADAL, E., 2004. El análisis antracológico de los restos del fuego doméstico del abrigo de Los Baños (Ariño, Teruel). In P. Utrilla \& J. M. Rodanés (eds.) Un asentamiento epipaleolitico en el valle del río Martín. El abrigo de Los Baños (Ariño, Teruel). Monografías Arqueológicas Universidad de Zaragoza, 39: 63-74.

BADAL, E., in press. El combustible y el paisaje vegetal prehistórico del Cabezo de la Cruz (Zaragoza). In Picazo, J. \& Rodanés, J. M. Excavaciones Arqueológicas en el Cabezo de la Cruz.
Bernard, V., 1998. L'homme, le bois et la forêt dans la France du nord entre le Mésolihique et le haut Moyen Age. Oxford. BAR International Series, 733.

Bosch i Lloret, A., Chinchilla Sánchez, J. and Tarrús i Galter, J. (coords.), 2000. El poblat lacustre neolític de La Draga. Excavacions de 1990 a 1998. Girona. Museu d'Arqueologia de Catalunya, Centre d'Arqueologia Subaquàtica de Catalunya. Monografies del CASC 2.

Carrión Marco, Y., 2005. Usos da madeira e paleovegetação. Estudo antracológico de Alcalar 7. In E. Morán \& R. Parreira (Coords.) Alcalar 7. Estudo e reabilitação de um monumento megalitico: 149-172. Sagres.

Carrión, Y. and BADAL, E. 2004. La presencia de hongos e insectos xilófagos en el carbón arqueológico. Propuestas de interpretación. In M. J. Feliu Ortega, J. Martín Calleja, M. C. Edreira Sánchez, M. C. Fernández Lorenzo, M. P. Martínez Brell, A. Gil Montero, R. Alcántara Puerto (eds.) Avances en Arqueometría 2003. Cádiz, Servicio de Publicaciones de la Universidad de Cádiz: 98-106.

Chabal, L., 1997. Forêts et sociétés en Languedoc (Néolithique final, Antiquité tardive), L'anthracologie, méthode et paléoécologie. Documents d'Archéologie Française, Paris.

Elósegui Aldasoro, J., Ursúa Sesma, C. and Arbilla Ibáñez, J., 1990. Las Bardenas Reales. Mapa escala 1:50.000. Servicio Geográfico del Ejército. Gobierno de Navarra.

Elósegui Aldasoro, J. and Ursúa Sesma, C., 1994. Las Bardenas Reales. Pamplona. Fondo de publicaciones del Gobierno de Navarra.

EsAu, K., 1985. Anatomía vegetal. Barcelona. Ed. Omega.

ESPER, J., 2000. Long-term tree-ring variations in Juniperus at the upper timber-line in the Karakorum (Pakistan). The Holocene, 10 (2): 253-260.

Fabre, L., 1996. Le charbonnage historique de la chênaie à Quercus ilex L. (Languedoc, France): conséquences écologiques. 2 Vol. Thèse. Université Montpellier II.

Greguss, P., 1955. Identification of Living Gymnosperms on the Basis of Xylotomy. Akadémiai Kiado Budapest.

Greguss, P., 1959. Holzanatomie der Europaïschen Laubhölzer und Straücher. Akadémiai Kiado Budapest.

Hunot, J.-Y., 2000. Les restes de bois carbonisés provenant de constructions médiévales angevines. Rennes. Mémoire complémentaire, Université de Rennes 2, DEA ART.

IRIARTE, M. J., 1992. El entorno vegetal en las Bardenas Reales (Navarra) durante la Prehistoria reciente. Cuadernos de Sección. Historia, 20: 359-367. Eusko Ikaskuntza, Donosita.

IRIARTE, M. J., 2001. Un caso paradigmático de antropización del medio vegetal. El poblado de la Edad del Bronce de Puy Águila I (Bardenas Reales, Navarra). Trabajos de Arqueología Navarra, 15: 123-136. Pamplona.

Jacquiot, C., 1955. Atlas d'anatomie des bois des coniferes. Cent. Tech. Bois. Paris. 
Jacquiot, C, Trenard, Y. and Dirol, D., 1973. Atlas d'anatomie des bois des angiospermes (Essences feuillues). Cent. Tech. Bois. Paris.

Kaennel, M. and Schweingruber, F. H., 1995. Multilingual Glossary of Dendrochronology.

Lull, V., Micó, R. Rihuete, C. and Risch, R. 1999. Ideología y sociedad en la prehistoria de Menorca: La Cova des Càrritx y la Cova des Mussol (Ciutadella). Barcelona.

Marguerie, D., 1992a. Évolution de la végétation sous l'impact humain en Armorique du Néolithique aux périodes historiques. Rennes. Travaux du Laboratoire d'Anthropologie de Rennes, n 40.

Marguerie, D., 1992b. Charbons de bois et paléoenvironnement atlantique. Les bois archéologiques, dossier $n^{\circ} 2$ A.G.O.R.A. Laboratoire d'Anthropologie de l'Université de Rennes 1: 1519. Rennes.

Marguerie, D., 1995a. L'état du milieu forestier durant la Protohistoire et l'Antiquité en Bretagne. L'apport de l'anthracologie. In J. Cl. Beal (ed.). L'arbre et la forêt, le bois dans l'Antiquité. Paris. Publications de la Bibliothèque Salomon-Reinach. Université Lumière-Lyon 2, VII: 27-33.

Marguerie, D., 1995b. Paléoenvironnement des monuments mégalithiques de Saint-Just. Les études archéobotaniques. In J. Briard, M. Gautier, G. Leroux (dirs.). Les mégalithes et les tumulus de Saint-Just (Ille-et-Vilaine) : évolution et acculturation d'un ensemble funéraire. Paris. Ed. du Comité des Travaux historiques et scientifiques: $128-142$.

Marguerie, D., 1998. Les charbons de bois. In G. San Juan, J.-L. Dron. Le site néolithique moyen de Derrière-les-Près à Ernes (Calvados). Paris. CNRS Editions: 151-237. Extrait de Gallia Préhistorique, 39, 1997.

Marguerie, D. and Hunot J.-Y., 2007. Charcoal analysis and dendrology: data from archaeological sites in western France. Journal of Archaeological Sciences, 34: 1417-1433.

Marguerie, D. and Marcoux, N., 2001. Environnement des sépultures de l'Age du Bronze de Balchoïkazakhbaïevo (Oural, Russie). Revue d'Archéologie de l'Ouest, supplément no 9: 241-243.

Metcalfe, C. R., 1960. Anatomy of Monocotyledons. I. Gramineae. Oxford. Ed. The Cjarendon Press.

Metcalfe, C. R. and Chalk, L., 1950. Anatomy of Dycotiledons. Oxford.

Munaut, A.-V., 1988. Les cernes de croissance des arbres (la dendrocrhonologie). In L. Genicot (dir.). Typologie des sources $d u$ Moyen-Age occidentale, B III-2 (53): 1-51. Brepols TurnhoutBelgium.

Pétrequin, P. (dir.), 1989. Les sites littoraux Néolithiques de Claivaux-les-Lacs (Jura). II Le Néolithique Moyen. Paris. Éditions de la Maison des Sciences de l'Homme.

Pétrequin, P. (dir.), 1997. Les sites littoraux Néolithiques de Claivaux-les-Lacs et de Chalain (Jura). III Chalain Station 3. 3200-2900 av. J.-C. Vol. 1 y 2. Paris.
Pétrequin, P. and Pétrequin, A-M., 1989. Habitat lacustre de Bénin. Une approche ethno-archéologique. Paris. Éditions Recherche sur les Civilisations.

Rivas-Martínez, S., 1987. Memoria del mapa de series de vegetación de España 1: 400.000. I.C.O.N.A. Madrid.

Rodanés, J. M. and Picazo, J., 2006. La excavación arqueológica. En Caminos para el futuro, ventanas hacia el pasado: 7-60. Diputación provincial de Zaragoza.

Scheel-Ybert, R., 1998. Stabilité de l'écosystème sur le littoral Sud-Est du Brésil à l'Holocène Supérieur (5500-1400 ans BP). Les pêcheurs-cueilleurs-chasseurs et le milieu végétal: apports de l'anthracologie. Thèse. Université Montpellier II, Sciences et Techniques du Languedoc.

SchweIngruber, F. H., 1978. Mikroskopische holzanatomie. Zürcher, AG, Zug.

SChweIngruber, F. H., 1990. Anatomie europäischer Hölzer. Bern und Stuttgart. Haupt.

Schweingruber, F. H., 1996. Tree Rings and Environment. Dendroecology. Berne, Paul Haupt Publishers.

Sesma Sesma, J., 1993. Aproximación al problema del hábitat campaniforme. El caso de las Bardenas Reales de Navarra, Cuadernos de Arqueología de la Universidad de Navarra, 1: 53119. Pamplona.

TARDY, C., 1998. Anthracologie. In S. Vacher, S. Jérémy, J. Briand (dir.). Amérindiens du Sinnamary (Guyane). Archéologie en forêt équatoriale: 94-102. Documents d'Archéologie Française, $\mathrm{n}^{\circ} 70$.

Théry-Parisot, I., 2001. Économie des combustibles au Paléolitique. Expérimentation, taphonomie, anthracologie. CNRS Éditions. Dossier de Documentation Archéologique, nº 20.

Thinon, M., 1992. L'analyse pédoanthracologique: aspects méthodologiques et applications. Thèse, Aix-Marseille 3.

Valero-Gracés, B. L., Navas, A., Machin, J., Stevenson, T. and DAVIs, B., 2000a. Responses of a saline lake ecosystem in a semiarid region to irrigation and climatic variability. Ambio, 6: 344-350.

Valero-Gracés, B.L., Gonzáles-Sampériz, P., Delgado-Huertas, A., Navas, A., Machin, J. and Kelts, K., 2000b. Lateglacial and Late Holocene environmental and vegetational change in Salada Mediana, central Ebro Basin, Spain. Quaternary International, 73/74: 29-46.

VERNET, J.-L., 1973. Étude sur l'histoire de la végétation du sud-est de la France au Quaternaire, d'après les charbons de bois principalement. Montpellier. Paléobiologie Continentale, 4 (1).

Vernet, J.-L., Bazile, E. and Evin, J., 1979. Coordination des analyses anthracologiques et des datations absolues sur charbons de bois. Bull. Soc. Préhist. Fr., 76 (3): 76-79.

ArcheoSciences, revue d'archéométrie, 31, 2007, p. 151-161 